\title{
Methanol Extract of Rumex Vesicarius L. as Eco- Friendly Corrosion Inhibitor for Carbon Steel in Sulfuric Acid Solution
}

\author{
A. S. FOUDA ${ }^{1 *}$, K. SHALABI ${ }^{1}$, A. M. NOFAL ${ }^{2}$ and M. A. EL-ZEKRED ${ }^{1}$ \\ ${ }^{1}$ Chemistry Department, Faculty of Science, Mansoura University, El-Mansoura, Egypt \\ ${ }^{2}$ Environmental Studies and Research Institute, University of EL-Sadat City, Egypt \\ asfouda@hotmail.com
}

Received 14 July 2017 / Accepted 26 August 2017

\begin{abstract}
The inhibiting effect of Rumex vesicarius L. extract on the carbon steel corrosion in $\mathrm{H}_{2} \mathrm{SO}_{4}$ was studied by weight loss, potentiodynamic polarization, electrochemical frequency modulation and electrochemical impedance techniques. The efficiency of the extract increased with increasing the extract concentration and with rising the temperature. The $\mathrm{E}_{\mathrm{a}}{ }^{*}$ (activation energy) and other parameters for the corrosion procedure have also been measured and discussed. potentiodynamic polarization measurements specified that this extract acts as mixed type inhibitor and chemically adsorbed on carbon steel surface following the Temkin isotherm. The data from different tests are in excellent agreement.
\end{abstract}

Keywords: Rumex vesicarius extract, EIS, EFM, SEM, Potentiodynamic polarization

\section{Introduction}

Carbon steel is the greatest useful substance which utilized as a material constructional in several productions and this is due to its outstanding mechanical properties and little price. Acidic solutions are utilized in several procedures such as; pickling of metals to eliminate scale, oil refinery by chemical procedures, components in rocket tools etc. ${ }^{1-4}$. Corrosion is the demolition of alloys and metals by electrochemical and chemical reactions with its environment. This phenomenon can be controlled and prevented using several methods ${ }^{5,6}$. Corrosion inhibitors are widely used in industry for protecting a metal against Corrosion. There are several research have been distributed on the utilized of nature produces as corrosion protection $^{7-21}$. Plant extracts utilized as corrosion protection are safe environment and economic. A lot of plant extracts employed as effect as corrosion protection for carbon steel in solution of $\operatorname{acid}^{22-24}$. The plant under studied is Rumex vesicarius which are edible. The leaves of greatest kinds include tannin and oxalic acid and many have slightly and astringent purgative potentials. This plant belongs to the family of Polygonaceae. In this paper the inhibiting effect of Rumex vesicarius L. extract on the carbon steel (CS) corrosion in $\mathrm{H}_{2} \mathrm{SO}_{4}$ was studied by using weight loss (WL), potentiodynamic polarization (PP), electrochemical frequency modulation (EFM) and electrochemical impedance (EIS) techniques. Morphology of surface was measured using SEM. 


\section{Experimental}

Composition of CS sample is: $0.060 \%$, P $0.0260 \%$ S, $0.10 \%$ C, $0.40 \% \mathrm{Mn}$ and Fe rest. The coupons measure $2.0 \times 2.0 \times 0.2 \mathrm{~cm}$ were abraded to finish a mirror with help of emery paper of different grades and washed with second distilled water and dried utilizing filter papers.

\section{Preparation of plant extracts}

Plant material Rumex vesicarius were dried in the shade at room temperature, ground using electrical mill into fine powder and extracted by soaking in methanol. The solvent from extracts was removed and dried under vacuum at $60-65{ }^{\circ} \mathrm{C}$ using a rotary evaporator. The solid of the extract was liquefied in second distilled water $(1 \mathrm{~g} / \mathrm{L})$. The crude extracts were preserved under refrigeration until use $\mathrm{u}^{25}$.

\section{Weight loss method}

The specimens were abraded with emery paper, cleaned by second distilled water and lastly dried between two filter papers and weighed. The samples were dipped in $100 \mathrm{~mL}$ of $0.5 \mathrm{M}$ of $\mathrm{H}_{2} \mathrm{SO}_{4}$ in existence and nonexistence of various concentration of the extract. The concentration range of Rumex vesicarius extract used was varied from 50 to $300 \mathrm{ppm}$. The immersion time intervals from 30 to $180 \mathrm{~min}$. After specified periods of time, the coins were weighed again. The corrosion rates (CR) of the metal specimens were measured using the following relationship ${ }^{26}$ :

$$
\mathrm{CR}=\Delta \mathrm{W} / \mathrm{At}
$$

$\mathrm{CR}=$ corrosion rate, $\Delta \mathrm{W}=$ reduction in mass $(\mathrm{mg}), \mathrm{A}=$ surface area $\left(\mathrm{cm}^{2}\right), \mathrm{t}=$ time $(\mathrm{min})$. The protection efficiency (IE\%) was obtained from Eq.2.

$$
\mathrm{IE} \%=100 \times\left[1-\left(\Delta \mathrm{W}_{1} / \Delta \mathrm{W}_{2}\right)\right]
$$

Where, $\Delta \mathrm{W}_{2}$ and $\Delta \mathrm{W}_{1}$ are the weight losses in nonexistence and existence of the extract, respectively.

\section{Electrochemical techniques}

A three electrode cell assembly was used for electrochemical measurements. They were arranged in a glass cell. (SCE) saturated calomel electrode as a reference electrode, a platinum counter electrode as auxiliary electrode and CS as a working electrode. The working electrode was made of square specimen of CS with area $1 \mathrm{~cm}^{2}$. The electrode surface was treated in the same manner as in the weight loss test. All tests were performed at temperature $\left(25.0{ }^{\circ} \mathrm{C}\right)$. Before starting the measurements, the potential of electrode was studied for $25 \mathrm{~min}$. Measurements were performed by Gamry apparatus (PCI4/750) with Gamry classification depends on the ESA 400 and computer frame works software DC 105 for PP tests, software EFM140 for EFM and software EIS 300 for EIS.

\section{Electrochemical frequency modulation measurements}

Two frequencies $2,5 \mathrm{~Hz}$ were used as potential perturbation ${ }^{27}$, with frequency $=0.1 \mathrm{~Hz}$ was used for EFM test. The (CF-2 and CF-3) causality factors, ( $i_{\text {corr }}$ ) and $\beta_{a}$ and $\beta_{c}$ were calculated by using the biggest peeks ${ }^{28}$.

\section{Electrochemical impedance measurements}

Open circuit potential (OCP) has been used and current signals in frequency range from $100 \mathrm{kHz}$ to $10 \mathrm{~Hz}$ for impedance measurements. The $\theta$ and $\% \mathrm{IE}$ were calculated using the following Eq. 3

$$
\mathrm{IE} \%=100 \times\left[1-\mathrm{R}_{\mathrm{ct}(\mathrm{free})} / \mathrm{R}_{\mathrm{ct} \text { (inh) }}\right]
$$

Where $R_{c t(f r e e)}$ and $R_{c t(i n h)}$ are the resistances without and with inhibitors individually. 


\section{Potentiodynamic polarization tests}

Potentiodynamic polarization scan used to obtain Tafel curves by sweeping the working potential from -700 to $700 \mathrm{mV}$ at scan rate $1 \mathrm{mVs}^{-1}$. $\mathrm{i}_{\text {corr }}$ was calculated by extrapolation of cathodic and anodic Tafel lines to gives $\log \mathrm{i}_{\text {corr }}$ and $\mathrm{E}_{\text {corr }} \cdot \theta$ and $\% \mathrm{IE}$ were given from the EIS results using the below Eq 4.

$$
\text { IE } \%=100 \times\left[1-i_{\text {corr (inh) }} / i_{\text {corr (free) })}\right]=\theta \times 100
$$

Where $i_{\text {corr (inh) }}$ and $i_{\text {corr (free) }}$ are the currents for corrosion in the absence and presence of Rumex vesicarius extract, respectively.

\section{Results and Discussion}

The data of CR, $\theta$ and IE\% of CS in $\mathrm{H}_{2} \mathrm{SO}_{4}(0.5 \mathrm{M})$ solution in the various concentration of Rumex vesicarius extract are given in Table 1. The weight loss of CS in acidic solution in the absence and presence of various concentration of extract after various immersion time (30-180 min) at $25.0{ }^{\circ} \mathrm{C}$ are given in Figure 1. \% IE improved with increase the concentration of Rumex vesicarius and with increase in temperature. The \%IE is due to the adsorbed Rumex vesicarius extract on the CS and formation of a layer from adsorbed molecules on CS surface which isolates the surface of CS from acidic solution and blocking the sites of corrosion $^{29}$.

Table 1. Effect of different concentration of Rumex vesicarius extract on CR and IE\% of CS in $\mathrm{H}_{2} \mathrm{SO}_{4}$ at various temperatures

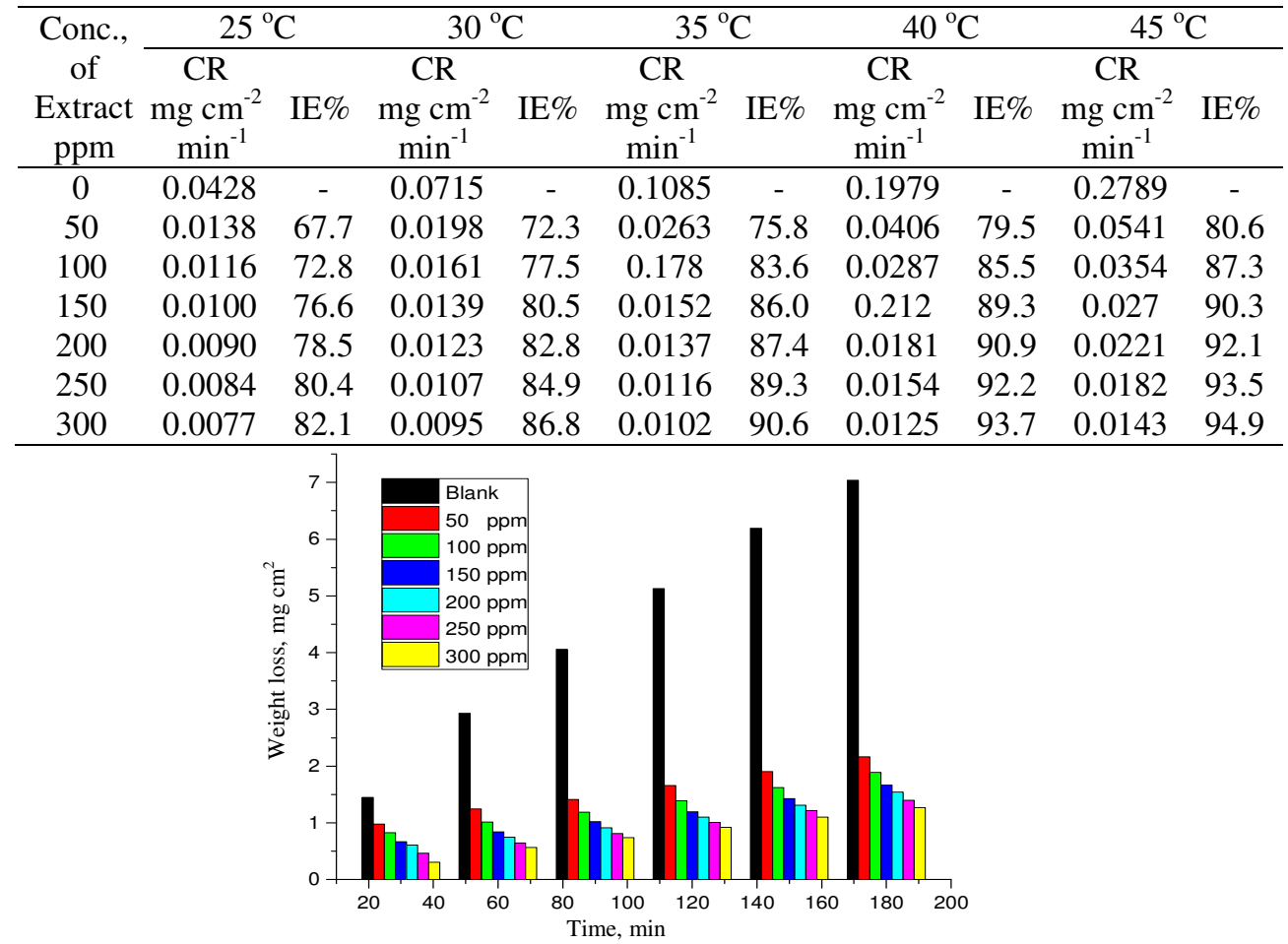

Figure 1. Weight loss of CS in acidic solution in the Rumex vesicarius extract at different concentration 


\section{Adsorption isotherms}

Rumex vesicarius extract is adsorbed on the CS surface due to that the interaction energy among the CS surface and the extract is more than that between $\mathrm{H}_{2} \mathrm{O}$ molecules and metal ${ }^{30,31}$. From the data the Temkin model adsorption isotherms fit in the excellent manner (Figure 2). The Temkin adsorption isotherm may be expressed by:

Where $\mathrm{C}=$ concentration of the extract

$$
\mathrm{a} \theta=\ln \mathrm{K}_{\mathrm{ads}} \mathrm{C}
$$

Table 2. Thermodynamic adsorption parameters

\begin{tabular}{ccccc}
\hline $\mathrm{T}, \mathrm{K}$ & $\log \mathrm{K}_{\mathrm{ads}}$ & $-\Delta \mathrm{G}_{\mathrm{ads},}^{\circ} \mathrm{kJ} \mathrm{mol}^{-1}$ & $\Delta \mathrm{H}_{\mathrm{ads},}^{\circ} \mathrm{kJ} \mathrm{mol}^{-1}$ & $\Delta \mathrm{S}_{\mathrm{ads},}^{\circ} \mathrm{J} \mathrm{mol}^{-1} \mathrm{~K}^{-1}$ \\
\hline 298 & 4.96 & 38.3 & & 407.7 \\
303 & 5.23 & 40.5 & & 408.1 \\
308 & 5.51 & 42.8 & 83.2 & 409.0 \\
313 & 5.71 & 44.7 & & 408.2 \\
318 & 5.88 & 46.4 & & 407.6 \\
\hline
\end{tabular}

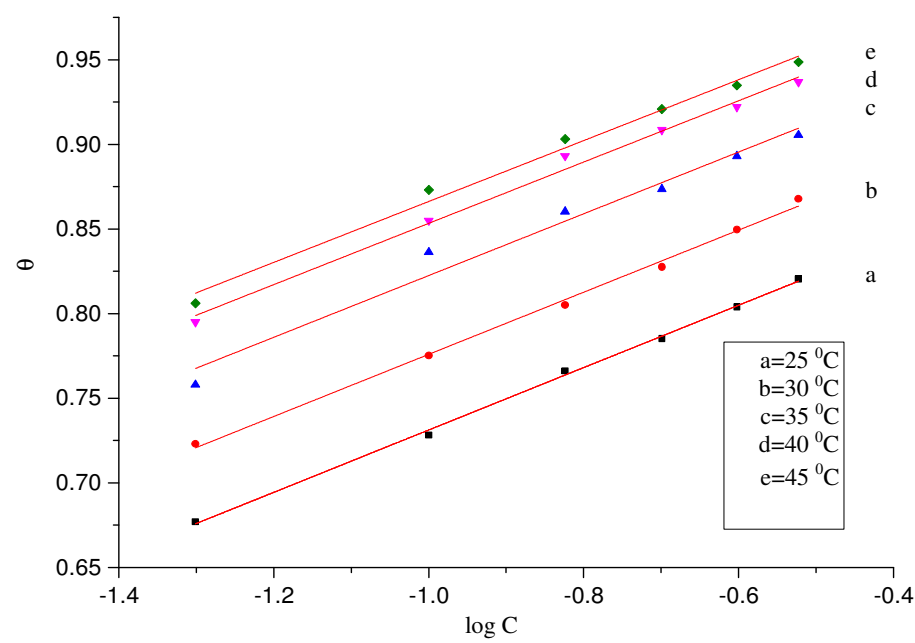

Figure 2. Temkin adsorption model of Rumex vesicarius extract on the CS surface at different temperatures

\section{Thermodynamic parameters}

The thermodynamic parameters such as; $\Delta \mathrm{G}^{\circ}, \Delta \mathrm{S}^{*}, \Delta \mathrm{H}^{*}$ and $\mathrm{Ea}^{*}$ were calculated ${ }^{32-34}$ from the corrosion rate data obtained from weight loss experiments using the equation 6 and listed in the Table 2. Ea ${ }^{*}$ was estimated from Arrhenius equation $7:^{35}$

$$
\begin{gathered}
\Delta \mathrm{G}_{\mathrm{ads}}^{\circ}=\Delta \mathrm{H}_{\mathrm{ads}}^{\circ}-\mathrm{T} \Delta \mathrm{S}_{\mathrm{ads}}^{\circ} \mathrm{K}_{\mathrm{ads}}=(1 / 55.5) \exp \left(-\Delta \mathrm{G}_{\mathrm{ads}}^{\circ} / \mathrm{RT}\right) \\
\mathrm{k}=\mathrm{A} \exp \left(-\mathrm{Ea}^{*} / \mathrm{RT}\right)
\end{gathered}
$$

Where $\mathrm{A}=$ Arrhenius constant, $\mathrm{R}=$ gas constant and $\mathrm{k}=$ rate of corrosion. Figure 3 was plotted between $\log \mathrm{k}_{\text {corr }} v s .1 / \mathrm{T}$ for various concentration of Rumex vesicarius extract. From the figure the $\mathrm{Ea}^{*}$ value can be calculated from the slope of the line. The $\Delta \mathrm{H}^{*}$ and the $\Delta \mathrm{S}^{*}$ can be computed using another formula of transition state expression:

$$
\mathrm{k}=(\mathrm{RT} / \mathrm{Nh}) \exp \left(\Delta \mathrm{S}^{*} / \mathrm{R}\right) \exp \left(\Delta \mathrm{H}^{*} / \mathrm{RT}\right)
$$


Where, $\mathrm{h}=$ Planck s constant and $\mathrm{N}=$ Avogadro s number. The data of $\Delta \mathrm{H}^{*}$ and $\Delta \mathrm{S}^{*}$ can be measured by plotting $\log \left(\mathrm{k}_{\mathrm{corr}} / \mathrm{T}\right)$ vs. $1 / \mathrm{T}$ (Figure 4). The data of $\mathrm{Ea}^{*}, \Delta \mathrm{S}^{*}$ and $\Delta \mathrm{H}^{*}$ are shown in Table 3.

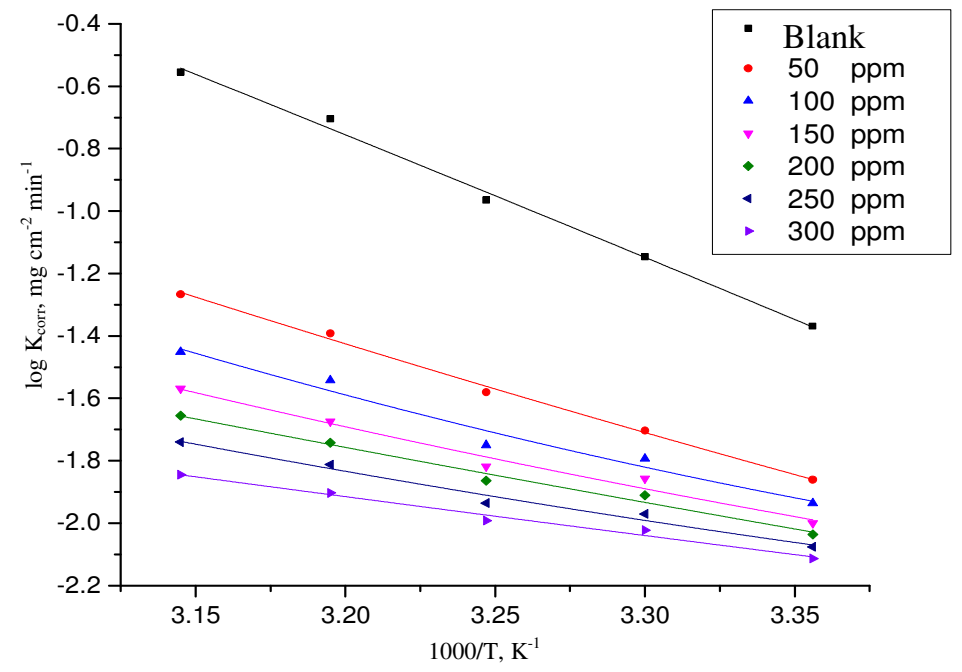

Figure 3. $\log \mathrm{k}_{\mathrm{corr}} v s .1 / \mathrm{T}$ curves for various concentration of Rumex vesicarius extract

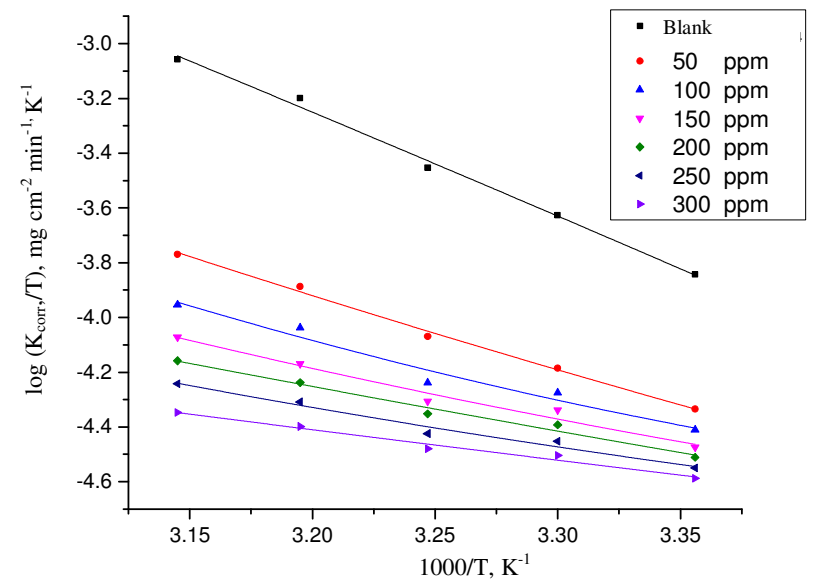

Figure 4. $\log \left(\mathrm{k}_{\mathrm{corr}} / \mathrm{T}\right)$ vs. $1 / \mathrm{T}$ diagram for various concentration of Rumex vesicarius extract

Table 3. Thermodynamic parameters for corrosion of CS at different concentration of Rumex vesicarius extract in $0.5 \mathrm{M} \mathrm{H}_{2} \mathrm{SO}_{4}$ solution

\begin{tabular}{cccc}
\hline $\mathrm{C}_{\mathrm{inh}}, \mathrm{ppm}$ & $\mathrm{E}_{\mathrm{a}}{ }^{*}, \mathrm{~kJ} \mathrm{~mol}^{-1}$ & $\Delta \mathrm{H}^{*}, \mathrm{~kJ} \mathrm{~mol}^{-1}$ & $-\Delta \mathrm{S}^{*}, \mathrm{~J} \mathrm{~mol}^{-1} \mathrm{~K}^{-1}$ \\
\hline 0 & 75.2 & 31.6 & 27.3 \\
50 & 54.4 & 22.5 & 106.6 \\
100 & 44.3 & 18.1 & 142.1 \\
150 & 37.9 & 15.4 & 164.3 \\
200 & 33.8 & 13.6 & 179.1 \\
250 & 30.1 & 11.9 & 192.2 \\
300 & 23.9 & 9.3 & 213.8 \\
\hline
\end{tabular}




\section{Potentiodynamic polarization measurements}

The potentiodynamic polarization curves for CS in the various concentration of Rumex vesicarius extract at $25{ }^{\circ} \mathrm{C}$ are shown in Figure 5. From the figure, one can noted that both (discharge hydrogen) cathodic and (CS dissolution) anodic reactions were inhibited by adding various concentration of Rumex vesicarius extract. Both $\beta_{\mathrm{a}}$ and $\beta_{\mathrm{c}}$ were moved to positive and negative directions, respectively. The electrochemical parameters, $E_{\text {corr }}, \beta_{\mathrm{a}}$ and $\beta_{\mathrm{c}}, \theta$, IE $\%$ and $\mathrm{i}_{\text {corr }}$ were measured and given in Table 4. Data shows that by addition of extract the values of $i_{\text {corr }}$ were lowered while the values of $E_{\text {corr }}$ and $\beta_{a}$ and $\beta_{c}$ had no significant change. So the Rumex vesicarius extract performance as mixed type inhibitor.

Table 4. Electrochemical parameter, $\mathrm{i}_{\text {corr }}, \mathrm{E}_{\text {corr }}, \beta_{\mathrm{a}}, \beta_{\mathrm{c}}, \mathrm{k}_{\text {corr }}, \theta$ and IE\% of CS in $0.5 \mathrm{M} \mathrm{H}_{2} \mathrm{SO}_{4}$ in the various concentration of Rumex vesicarius extract

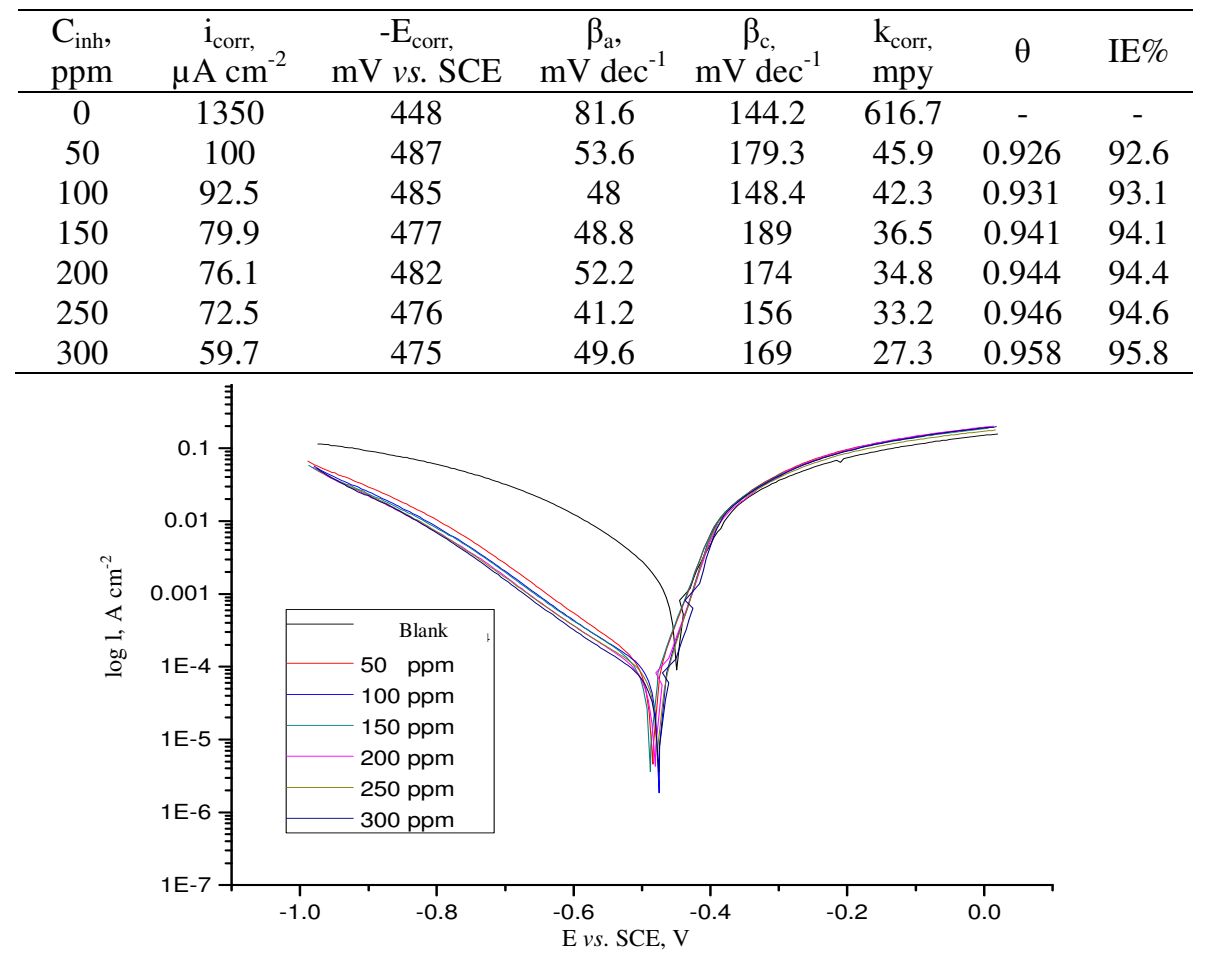

Figure 5. Potentiodynamic polarization diagram for $\mathrm{CS}$ in $0.5 \mathrm{M} \mathrm{H}_{2} \mathrm{SO}_{4}$ in the various concentration of Rumex vesicarius extract at $25^{\circ} \mathrm{C}$

\section{EFM Tests}

The data obtained from EFM for CS in $0.5 \mathrm{M} \mathrm{H}_{2} \mathrm{SO}_{4}$ at various concentration of Rumex vesicarius extract at $25{ }^{\circ} \mathrm{C}$ were measured and are listed in Table 5. The data observed that, the corrosion current densities decrease by increasing the concentration of Rumex vesicarius extract while the inhibition efficiency (IE\%) increases. The causality factors are close to their theoretical values. The values of $i_{\text {corr }}$ can be obtained directly from EFM measurements and independent of the knowledge of Tafel constants. The IE\% can be calculated as in Eq. 4. The intermodulation spectra obtained from EFM in absence and presence of different concentration of Rumex vesicarius extract are shown in Figure 6(a-g). 
Table 5. EFM for CS in the various concentration of Rumex vesicarius extract at $25{ }^{\circ} \mathrm{C}$

\begin{tabular}{ccccccccc}
\hline $\begin{array}{c}\text { Conc., of } \\
\text { Extract, ppm }\end{array}$ & $\begin{array}{c}\mathrm{i}_{\text {corr, }} \\
\mu \mathrm{A} \mathrm{cm}^{-2}\end{array}$ & $\begin{array}{c}\beta_{\mathrm{a},} \\
\mathrm{mV} \mathrm{dec}^{-1}\end{array}$ & $\begin{array}{c}\beta_{\mathrm{c},} \\
\mathrm{mV} \mathrm{dec}^{-1}\end{array}$ & $\mathrm{CF}-2$ & $\mathrm{CF}-3$ & $\begin{array}{c}\mathrm{k}_{\text {corr, }} \\
\mathrm{mpy}\end{array}$ & $\theta$ & IE\% \\
\hline 0 & 2217 & 116.3 & 152.4 & 1.91 & 5.06 & 1.01 & - & - \\
50 & 148.9 & 62.4 & 162.8 & 1.97 & 3.18 & 68.1 & 0.933 & 93.3 \\
100 & 144.8 & 61.1 & 139.7 & 1.95 & 3.34 & 66.2 & 0.935 & 93.5 \\
150 & 137.3 & 59.5 & 187.7 & 1.92 & 3.03 & 62.7 & 0.938 & 93.8 \\
200 & 132.9 & 59.7 & 157.9 & 1.96 & 2.90 & 60.7 & 0.940 & 94.0 \\
250 & 120.9 & 57.5 & 157.8 & 1.97 & 3.51 & 55.2 & 0.954 & 95.4 \\
300 & 107.8 & 59.0 & 157.5 & 1.90 & 3.62 & 49.3 & 0.951 & 95.1 \\
\hline
\end{tabular}

EIS measurements

The EIS of CS in the various concentration of Rumex vesicarius extract are shown in Figures 7(a-b) where Figure 7(a) is Nyquist plots and Figure 7(b) is Bode plots. The curves shows that there are gradual increases in the shape of each semicircle of the Nyquist curves by increasing the concentration of the extract. The obtained EIS parameters $\left(\mathrm{R}_{\mathrm{ct}}\right)$, the double layer capacitance $\left(\mathrm{C}_{\mathrm{dl}}\right)$ and the (IE\%) are listed in Table 6. These data shows there is an increase in $\left(\mathrm{R}_{\mathrm{ct}}\right)$ while the $\left(\mathrm{C}_{\mathrm{dl}}\right)$ decreased. Due to electrode surface homogeneities and the roughness, the curves obtained from the Nyquist plots are not perfect semicircle.
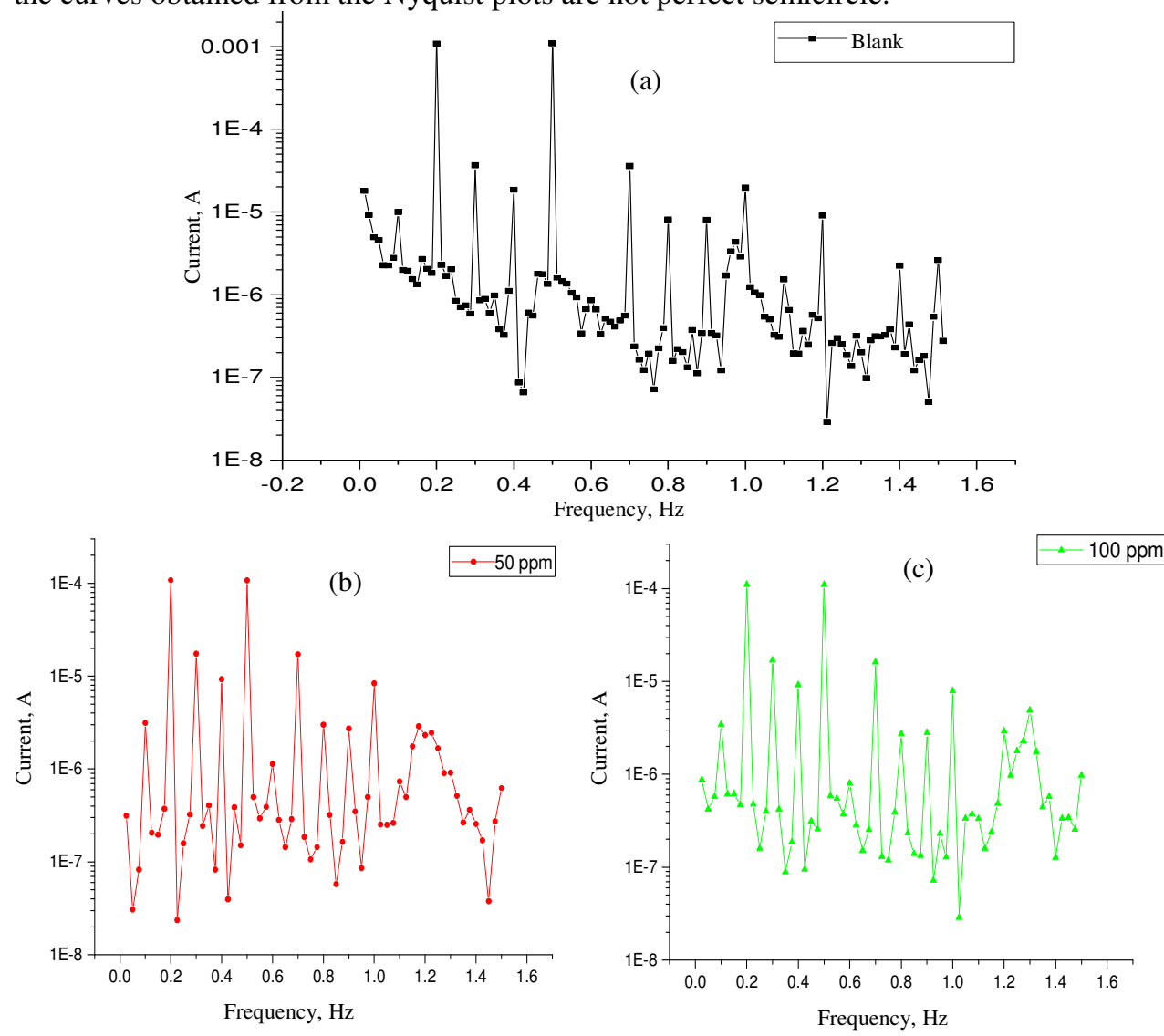

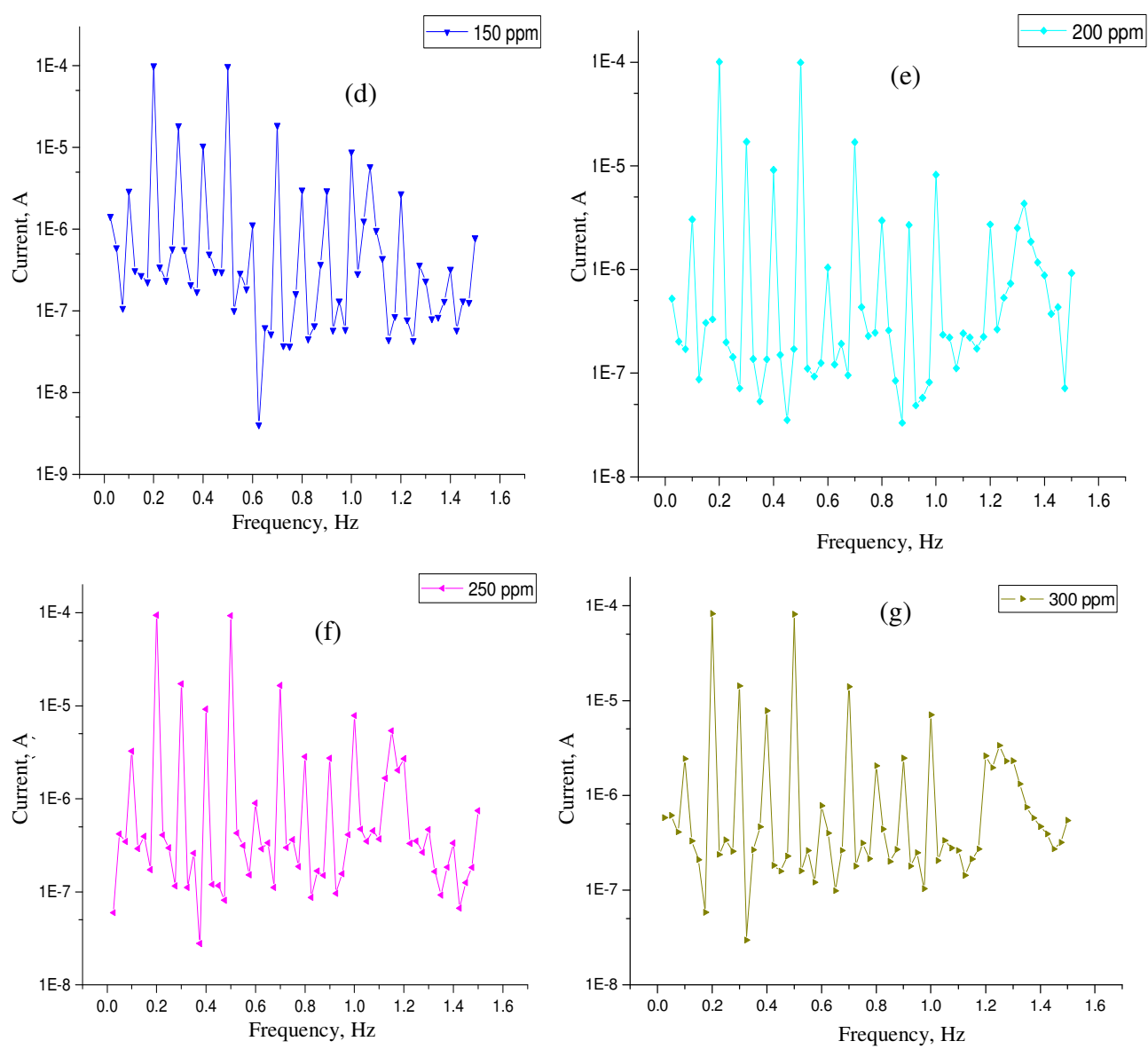

Figure 6. Intermodulation spectrum for $\mathrm{CS}$ in $0.5 \mathrm{M} \mathrm{H}_{2} \mathrm{SO}_{4}$ in the various concentration of Rumex vesicarius extract

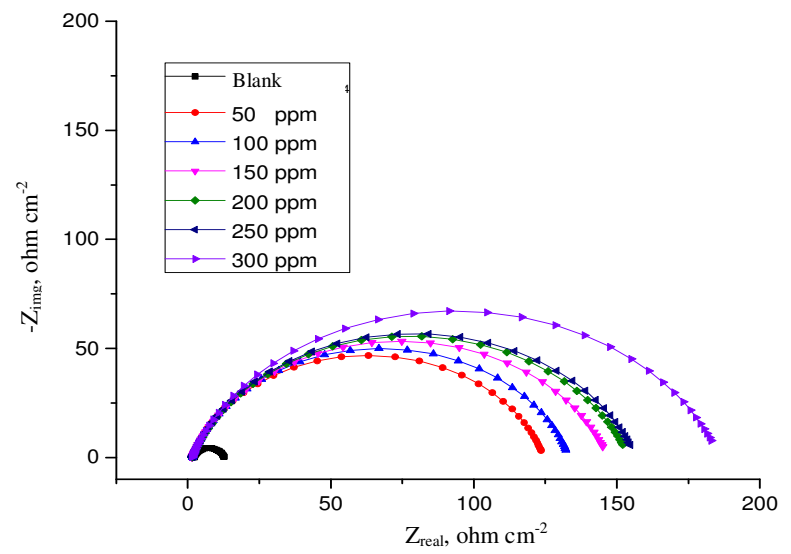

Figure 7(a). Nyquist diagrams for CS in the various concentration of Rumex vesicarius extract 


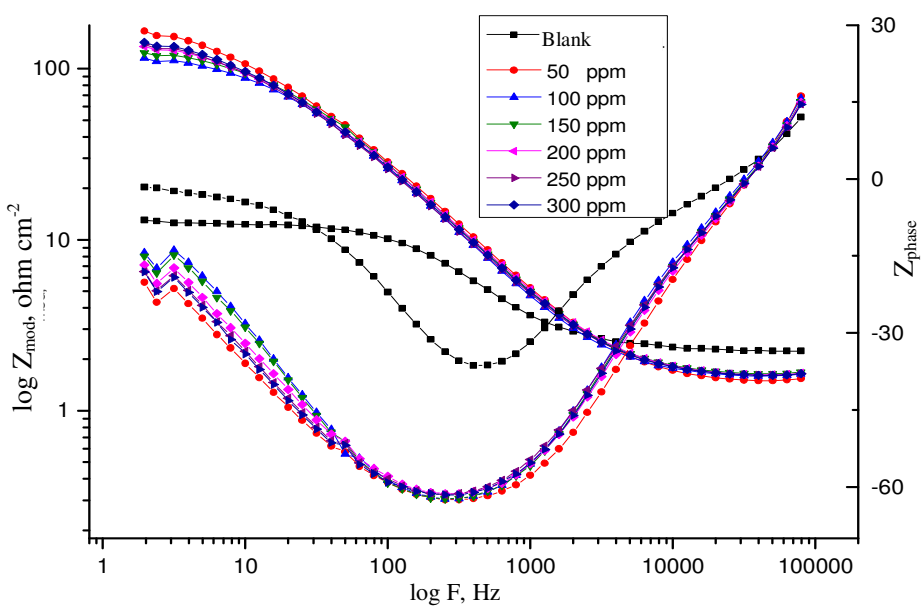

Figure 7(b). Bode curves for $\mathrm{CS}$ in $0.5 \mathrm{M} \mathrm{H}_{2} \mathrm{SO}_{4}$ for various concentration of Rumex vesicarius extract

Table 6. Data from EIS measurements for CS corrosion in the existence and nonexistence of various concentration of Rumex vesicarius extract at $25^{\circ} \mathrm{C}$

\begin{tabular}{ccccc}
\hline Conc., $\mathrm{ppm}$ & $\mathrm{R}_{\mathrm{ct}}, \Omega \mathrm{cm}^{2}$ & $\mathrm{C}_{\mathrm{dl}}, \mu \mathrm{F} \mathrm{cm}$ & $\theta$ & $\mathrm{IE} \%$ \\
\hline 0 & 10.36 & 96.1 & - & - \\
50 & 122.80 & 92.3 & 0.916 & 91.6 \\
100 & 131.7 & 90.1 & 0.921 & 92.1 \\
150 & 145.2 & 89.6 & 0.929 & 92.9 \\
200 & 153.0 & 86.3 & 0.932 & 93.2 \\
250 & 155.2 & 81.6 & 0.934 & 93.4 \\
300 & 184.7 & 77.6 & 0.944 & 94.4 \\
\hline
\end{tabular}

\section{SEM analysis}

The CS morphology surface was analyzed using SEM experiments after immersion in $0.5 \mathrm{M}$ $\mathrm{H}_{2} \mathrm{SO}_{4}$ in the absence and presence of $300 \mathrm{ppm}$ of Rumex vesicarius extract for $24 \mathrm{~h}$ immersion. Figure 8(a) shows the clear CS surface, Figure 8(b) gives the surface of the metal was damaged by $\mathrm{H}_{2} \mathrm{SO}_{4}$ and Figure 8 (c) shows the surface of the metal in presence of 300 ppm of Rumex vesicarius which does not affected by corrosion.

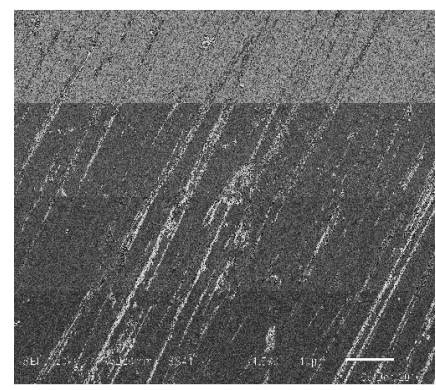

Figure 8(a). SEM of Pure metal

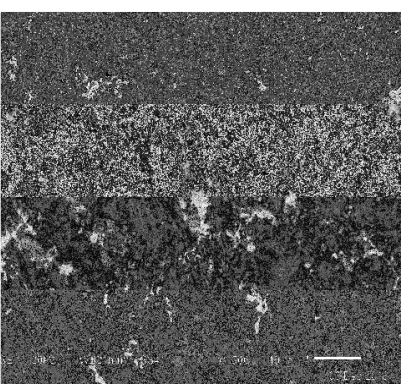

Figure 8(b). SEM of Metal $+\mathrm{H}_{2} \mathrm{SO}_{4}$

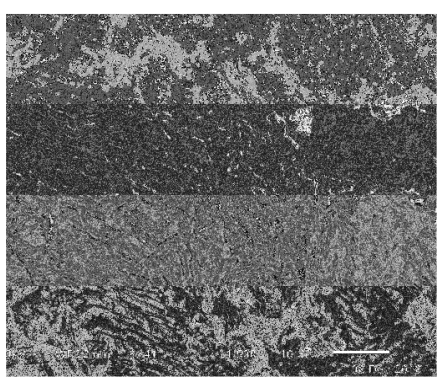

Figure 8(c). SEM of Metal + $\mathrm{H}_{2} \mathrm{SO}_{4}+300$ ppm of Rumex vesicarius 


\section{Explanation for inhibition}

This plant mainly contains anthraquinones, flavonoids, polyphenols lipids and sterols ${ }^{36}$. The adsorption on the CS surface (via the chemisorptions), include the movement of molecules of water from the CS surface and sharing of electrons among the iron and oxygen or Rumex vesicarius adsorb by donor-acceptor connections among vacant $\mathrm{d}$ orbitals of iron and $\pi$ electrons of the aromatic rings. In the acid medium steel surface bear's positive charge, so it is difficult to the protonated molecules to adsorb on the CS surface due to the electrostatic repulsion. $\mathrm{Cl}^{-}$ions get adsorbed on CS surface create an excess negative charge toward the solution and favor more adsorption for the cations ${ }^{37}$. Owing to the electrons lone-pair of $\mathrm{O}$ and $\mathrm{N}$ atoms in Rumex vesicarius molecules or the protonated molecules may association with freshly produced $\mathrm{Fe}^{2+}$ ions on the CS surface forming CS inhibitor complexes. These complexes adsorbed onto the CS by force (Van Der Waals) to form protecting cover to prevent CS from corrosion.

\section{Conclusion}

The inhibiting effect of Rumex vesicarius $\mathrm{L}$. extract on the carbon steel corrosion in $\mathrm{H}_{2} \mathrm{SO}_{4}$ was studied. The inhibition efficiency increases with the increase in the concentration of Rumex vesicarius extract. The Rumex vesicarius was adsorbed chemically and physically on the CS obeying Temkin isotherm. Results obtained from potentiodynamic polarization measurement indicate that this extract acts on both cathodic and anodic reactions (i.e. mixed type inhibitor). Results obtained from weight loss measurements and electrochemical tests are in excellent agreement.

\section{References}

1. Chauhan L R and Unasekaran G G, Corros Sci., 2007, 49(3), 1143-1161;

DOI:10.1016/j.corsci.2006.08.012

2. $\quad$ Lalitha A, Ramesh S and Rajeswari S, Electrochim Acta, 2005, 51, 47-55;

DOI:10.1016/j.electacta.2005.04.003

3. Quraishi M A and Sardar R, Corrosion, 2002, 58(2), 103-107;

DOI:10.5006/1.3277308

4. Abdel-Rehim S S, Khaled K F and Abd-Elshafi N S, Electrochim Acta, 2006, 51(16), 3269-3277; DOI:10.1016/j.electacta.2005.09.018

5 Putilova I N, Balezin S A, Barannik V P, Ryback G and Bishap E, (Eds.), Pergamon Press, 1960.

6. Ghulamullah khan, Kazi Md. Salim Newaz, Wan Jefrey Basirun, HapipahBintiMohd Ali, FadhilLafta Faraj and Ghulam Mustafa Khan, Int J Electrochem Sci., 2015, 10, $6120-6134$.

7. Odewunmi N A, Umoren S A and Gasem Z M, J Ind Eng Chem., 2015, 21, 239-247; DOI:10.1016/j.jiec.2014.02.030

8. Raja P B and Sethuraman M G, Mater Lett., 2008, 62(1), 113-116; DOI:10.1016/j.matlet.2007.04.079

9. $\quad$ Ekpe U J, Ebenso E E and Ibok U J, J West Afr Sci Assoc., 1994, 37, 13-30.

10. Ebenso E E, Ekpe U J, West Afr J Biol Appl Chem., 1996, 41, 21-27.

11. Avwiri G O and Igho F O, Mater Lett., 2001, 57, 3705-3711; DOI:10.1016/S0167577X(03)00167-8

12. El-Etre A Y and El-Tantawy Z, Port Electrochim Acta, 2006, 24, 347-356; DOI:10.4152/pea.200603347

13. Ebenso E E, Ibok U J and Ekpe U J, Trans SAEST, 2004, 39, 117-123. 
14. Okaforn P C, Ekpe U J, Ebenso E E, Oguzie E E, Umo N S and Etor A R, Trans SAEST, 2006, 41, 82-87.

15. Okafor P C, Osabor V I and Ebenso E E, Pigmenxt Resin Technol., 2007, 36(5), 299305; DOI:10.1108/03699420710820414

16. Okafor P C, Ekpe U J, Ebenso E E, Umoren E M and Leizou K E, Bull Electrochem., 2005, 21(1-3), 347-352

17. Oguzie E E, Onuchukwu A I, Okafor P C and Ebenso E E, Pigment Resin Technol., 2006, 35, 63-70; DOI:10.1108/03699420610652340

18. Oguzie E E, Pigment Resin Technol., 2006, 35, 334-340;

DOI:10.1108/03699420610711335

19. Shivakumar S S and Mohana K N, Adv Appl Sci Res., 2012, 3(5), 3097-3106.

20. Prabha K L, Rajam S and Venkatraman B R, Der Chemica Sinica., 2012, 3(1), 114-123.

21. Vimala J R, Rose A L and Raja S, Der Chemica Sinica., 2012, 3(3), 582-595.

22. Fouda A S, Gado H, Aboelmaaty W and Omar M, Elixir Corrosion Dye, 2016, 91, 38519-38526.

23. Banu V R N, Rajendran S and Kumaran S S, J Alloys Compds., 2016, 675, 139-148;

DOI:10.1016/j.jallcom.2016.02.247

24. Tezeghdenti M, Dhouibi L and Etteyeb N, J Bio Tribo Corros., 2015, 1, 16-25;

DOI:10.1007/s40735-015-0016-X

25. Dawood K M, Shabana Y M, Fayzalla E A and El-Sherbiny E A, J Agric Sci Mans Univ., 2003, 28, 5335-5349.

26. Quraishi M and Shukla S, Mater Chem Phys., 2009, 113(2-3), 685-689;

DOI:10.1016/j.matchemphys.2008.08.028

27. Khaled K, J Appl Electrochem, 2009, 39(3), 429-438; DOI:10.1007/s10800-008-9688-y

28. Bosch R W, Hubrecht J, Bogaerts W F and Syrett B C, Corrosion, 2001, 57(1), 60-70; DOI:10.5006/1.3290331

29. Zhang D Q, Cai Q R, He X M, Gao 1 X and Kim G S, Mater Chem Phys., 2013, 114(2-3), 612-617; DOI:10.1016/j.matchemphys.2008.10.007

30. Saleh M M and Atia A A, J Appl Electrochem., 2006, 36(8), 899-905;

DOI:10.1007/s10800-006-9147-6

31. Bockris J O and Swinkels D A J, J Electrochem Soc., 1964, 111(6), 736-748;

DOI:10.1149/1.2426222

32. Khamis E, Corrosion (NACE), 1990, 46, 476-484.

33. Popova A, Sokolova E, Raicheva S and Christov M, Corros Sci., 2003, 45, 33-58;

DOI:10.1016/S0010-938X(02)00072-0

34. Sherif E M and Park S M, Electrochim Acta, 2006, 51(22), 4665-4673;

DOI:10.1016/j.electacta.2006.01.007

35. Putilova I and Barannik S B, Pergamomon Press, New York, 1960, 31-37.

36. El-Harriry M Y, Cario University, 2012.

37. Bentiss F, Traisnet M and Lagrenee M, Corros Sci., 2000, 42(1), 127-136;

DOI:10.1016/S0010-938X(99)00049-9 